\title{
Germanium enrichment in supergene settings: evidence from the Cristal nonsulfide Zn prospect, Bongará district, northern Peru
}

\author{
Nicola Mondillo ${ }^{1,2} \cdot$ Giuseppe Arfè $^{1} \cdot$ Richard Herrington $^{2} \cdot$ Maria Boni $^{1} \cdot$ Clara Wilkinson $^{2} \cdot$ Angela Mormone $^{3}$
}

Received: 30 April 2017 / Accepted: 21 November 2017 / Published online: 8 January 2018

(C) The Author(s) 2018. This article is an open access publication

\begin{abstract}
Supergene nonsulfide ores form from the weathering of sulfide mineralization. Given the geochemical affinity of Ge to $\mathrm{Si}^{4+}$ and $\mathrm{Fe}^{3+}$, weathering of Ge-bearing sulfides could potentially lead to Ge enrichments in silicate and Fe-oxy-hydroxide minerals, although bulk rock Ge concentrations in supergene nonsulfide deposits are rarely reported. Here, we present the results of an investigation into Ge concentrations and deportment in the Cristal supergene $\mathrm{Zn}$ nonsulfide prospect (Bongará, northern Peru), which formed from the weathering of a preexisting Mississippi Valley-type (MVT) sulfide deposit. Material examined in this study originates from drillcore recovered from oxidized Zn-rich bodies $\sim 15-20 \mathrm{~m}$ thick, containing $\sim 5-45 \mathrm{wt} \% \mathrm{Zn}$ and Ge concentrations $\sim 100 \mathrm{ppm}$. Microanalysis and laser ablation-ICP-MS show that precursor sphalerite is rich in both $\mathrm{Fe}$ (mean $\mathrm{Fe}=8.19 \mathrm{wt} \%$ ) and $\mathrm{Ge}$ (mean $\mathrm{Ge}=142 \mathrm{ppm})$. Using the mineral geothermometer GGIMFis - geothermometer for $\mathrm{Ga}$, Ge, In, Mn, and Fe in sphalerite - proposed by Frenzel et al. (Ore Geol Rev 76:52-78, 2016), sphalerite trace element data from the Cristal prospect suggest a possible formation temperature $\left(T_{\mathrm{GGIMFis}}\right)$ of $225 \pm 50{ }^{\circ} \mathrm{C}$, anomalously high for a MVT deposit. Germanium concentrations measured in both goethite (mean values 100 to $229 \mathrm{ppm}$, max $511 \mathrm{ppm}$ ) and hemimorphite (mean values 39 to $137 \mathrm{ppm}$, max $258 \mathrm{ppm}$ ) are similar to concentrations measured in hypogene sphalerite. Additionally, the Ge concentrations recorded in bulk rock analyses of sphalerite-bearing and oxidized samples are also similar. A persistent warm-humid climate is interpreted for the region, resulting in the development of an oxidation zone favoring the formation of abundant $\mathrm{Zn}$ hydrosilicates and $\mathrm{Fe}$ hydroxides, both able to incorporate Ge in their crystal structure. In this scenario, Ge has been prevented from dispersion during the weathering of the Ge-bearing sulfide bodies and remains in the resultant nonsulfide ore.
\end{abstract}

Keywords Germanium · Zn nonsulfide deposits · Critical elements · Hemimorphite · Goethite · Sphalerite · Laser ablation LA-ICP-MS

Editorial handling: F. Melcher

Electronic supplementary material The online version of this article (https://doi.org/10.1007/s00126-017-0781-1) contains supplementary material, which is available to authorized users.

Nicola Mondillo

nicola.mondillo@unina.it; n.mondillo@nhm.ac.uk

1 Dipartimento di Scienze della Terra, dell'Ambiente e delle Risorse, Università degli Studi di Napoli Federico II, Complesso Universitario di Monte Sant'Angelo, Via Cintia, 80126 Naples, Italy

2 Department of Earth Sciences, Natural History Museum, Cromwell Road, London SW7 5BD, UK

3 INGV Osservatorio Vesuviano, Via Diocleziano 328, 80124 Naples, Italy

\section{Introduction}

Germanium, a key technology metalloid, is mainly recovered as a by-product from the mining of sphalerite-rich ores: from sediment-hosted massive $\mathrm{Zn}-\mathrm{Pb}-\mathrm{Cu}(-\mathrm{Ba})$ sulfide deposits, carbonate-hosted $\mathrm{Zn}-\mathrm{Pb}$ sulfide ores, polymetallic Kipushitype concentrations, and also from lignite and coal deposits (Höll et al. 2007; Melcher and Buchholz 2014; Paradis 2015; Frenzel et al. 2016). The bulk of Ge is produced in the following countries: (a) China (from lignite and the Huize, Jinding, and Fankou SHMS sediment-hosted massive sulfide deposits), (b) the USA (from the Red Dog SHMS deposit, Alaska, and the Mississippi Valley-type (MVT) concentrations of the Elmwood-Gordonsville district, TN), and (c) the Democratic Republic of the Congo (from treatment of slags of the Lubumbashi $\mathrm{Cu}-\mathrm{Zn}$ smelter and in part from slags 
originated from Kipushi). Germanium grades in these deposits range between 10 and 300 ppm (Melcher and Buchholz 2014, and references therein).

"Supergene nonsulfides" is a very general definition, used in the literature to describe a group of ore deposits mainly consisting of oxidized $\mathrm{Zn}-\mathrm{Pb}$ minerals, formed from the oxidation of sulfide-bearing ores in a weathering regime. Such deposits largely consist of $\mathrm{Zn}$ - and $\mathrm{Pb}$-carbonates (smithsonite, hydrozincite, and cerussite) and the $\mathrm{Zn}$-silicates hemimorphite, willemite, and sauconite (Large 2001; Hitzman et al. 2003). Weathering of sulfides has been shown to have increased the Ge grade in nonsulfide species only at Tsumeb (Namibia) and in the Apex deposit (USA) where, into the deeply weathered parts of the orebodies, primary germanite and renierite have been altered to secondary Geoxides (brunogeierite, otjisumeite, bartelkeite), Gehydroxides (stottite and manganostottite), sulfates (itoite, fleischerite, schaurteite), arsenates (olivenite, adamite), and silicates (willemite) (Melcher 2003; Höll et al. 2007, and references therein). Höll et al. (2007) point to the geochemical affinity of $\mathrm{Ge}$ with $\mathrm{Si}^{4+}$ and $\mathrm{Fe}^{3+}$, thus Ge concentrations are likely to be found in silicate minerals and Fe-oxy-hydroxides in supergene nonsulfide deposits derived from Ge-bearing sulfide protores. However, until now, the lack of information regarding the Ge concentrations has been taken to indicate that supergene nonsulfide $\mathrm{Zn}-\mathrm{Pb}$ deposits are poor targets for $\mathrm{Ge}$ recovery (Melcher and Buchholz 2014).

We present here the first results of a research aiming to fill the gap of knowledge on the Ge mineral residence in nonsulfide $\mathrm{Zn}$ deposits. In particular, we report on new data concerning Ge concentration and deportment in the Cristal supergene $\mathrm{Zn}$ nonsulfide mineralization (Northern Peru). The Cristal prospect is located in the Bongará district, an area of $\sim 400 \mathrm{~km}^{2}$ in the Peruvian inland, approximately $245 \mathrm{~km}$ northeast of the coastal city of Chiclayo and $740 \mathrm{~km}$ north of Lima. In the Bongará district, several years of $\mathrm{Zn}$ exploration have resulted in the discovery of two main $\mathrm{Zn}$ deposits, Mina Grande (ZincOne Resources Inc.) and Florida Canyon (Votorantim/ Milpo), and numerous $\mathrm{Zn}$ occurrences and prospects, considered potential satellites to bigger $\mathrm{Zn}$ deposits (Reid 2001; Basuki 2006; Basuki et al. 2008; Basuki and Spooner 2009; Arfè et al. 2017). The Cristal mineralization, one of the $\mathrm{Zn}$ nonsulfide prospects occurring in the Río Cristal area, is located $2 \mathrm{~km}$ north of the Mina Grande deposit (Arfè et al. 2017) and is currently at the exploration stage (ZincOne Resources Inc.).

This study was conducted on two of the most representative cores drilled in the Río Cristal area: drillcores CR13 and CR18, which intercepted stratabound $\mathrm{Zn}$-oxidized bodies of $15-20 \mathrm{~m}$ in thickness, with $\mathrm{Zn}$ grades ranging between $\sim 5$ and $\sim 45 \% \mathrm{Zn}$ (Brophy 2012). To determine the Ge concentration and mineral deportment within the mineralized interval, a comprehensive mineralogical, petrographic, and geochemical study of drillcore samples was carried out, including whole rock chemical and mineralogical analyses, complemented by laser ablation (LA)-ICP-MS analyses of selected minerals.

\section{Regional geological setting and mineralization}

The $\mathrm{Zn}$ mineralization of the Bongara district is hosted by lithologies of the Pucará Group, a 2000 m-thick sedimentary succession of Late Triassic to Early Jurassic age, which unconformably overlies the Middle-Late Triassic Mitu Group and the Paleozoic Marañon Complex (Fig. 1; Mišković et al. 2009; Reid 2001; Rosas et al. 2007; Spikings et al. 2016). The Pucará Group consists of shallow- to deep-water carbonates and comprises the Chambará, Aramachay, and Condorsinga Formations. The Chambará Formation (Norian-Rhaetian) consists of shallow-water carbonate rocks, and the overlying Aramachay Formation (RhaetianSinemurian) consists of deeper-water shaly limestones (Mathalone and Montoya 1995; Reid 2001; Brophy 2012; Rosas et al. 2007; Basuki et al. 2008). The Condorsinga Formation (Pliensbachian-Toarcian) is the uppermost unit of the Pucará Group and comprises shallow-water bioclastic and cherty limestones, locally containing a shaly to sandy component (Basuki et al. 2008; Brophy 2012). The Pucará Group is overlain in angular unconformity by the Upper Jurassic to Cretaceous Sarayaquillo Formation, a package of red shales, sandstones, and marls (Rosas et al. 2007). The Lower Cretaceous Goyllarisquizga Group in turn overlies the Sarayaquillo Formation. In the Bongará area, the youngest rocks belong to the Early Cretaceous Chonta-Choulec Formation (Brophy 2012).

The major tectonic events that produced the present-day Andean structure started in Early Cretaceous times, associated with the opening of the South Atlantic Ocean (Silver et al. 1998). Three major orogenic events are recorded from the Late Cretaceous to the present: the Peruvian, Incaic, and Quechua orogenies (84-79, 55-22, and 20.5-1.6 Ma; Klein et al. 2011). The northeastern part of the Peruvian morphostructural unit also experienced a Neogene phase of deformation from 20.5 to $1.6 \mathrm{Ma}$, expressed by a NE-vergent thrust system, largely responsible for the rise of the Eastern Cordillera (Mégard 1984; Gregory-Wodzicki 2000; Pfiffner and Gonzalez 2013). The Oligocene-Holocene phase of deformation produced most of the uplifts of the Andean Plateau and all the uplifts of the Subandean zone (Sempere et al. 1990; Jordan et al. 1997).

The Pucará Group is host to a range of MVT Zn-Pb deposits (Reid 2001), with the most important being the San Vicente and Shalipayco deposits (Fontboté and Gorzawski 1990; Gorzawski et al. 1990; Moritz et al. 1996; Spangenberg et al. 1996, 1999). In addition, the porphyry-related epithermal polymetallic ("Cordilleran") deposits of Cerro de Pasco 


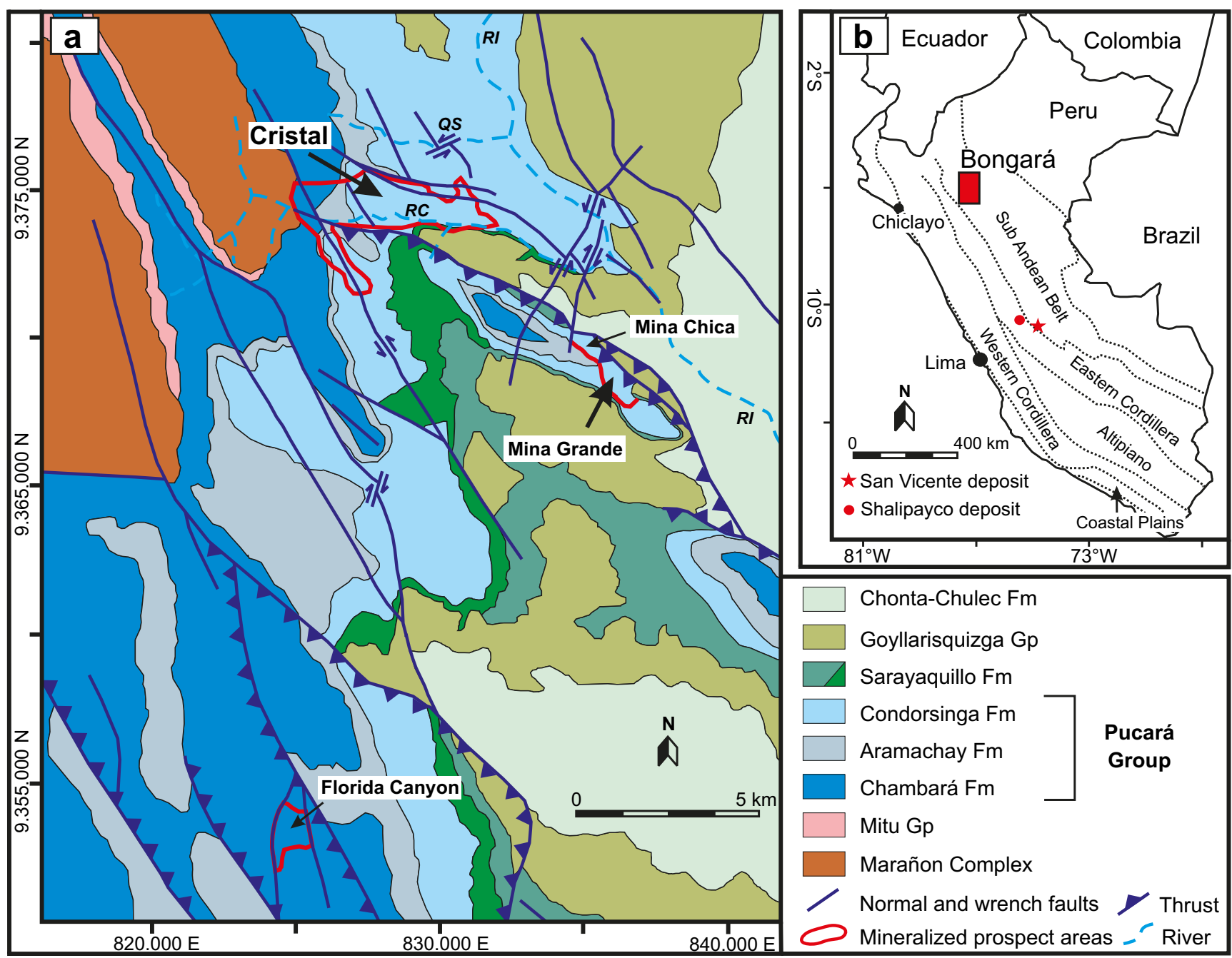

Fig. 1 Geological map (a) and location of the Bongará district within the Northern Andes morphostructural units (b) (UTM Zone 17, Datum WGS 84; modified from Arfè et al. 2017)

(Baumgartner and Fontboté 2008; Baumgartner et al. 2009; Rottier et al. 2016), San Gregorio in the Colquijirca district (Bendezú and Fontboté 2009) and the mines located in the Yauli Dome (e.g., San Cristobal, Carahuacra and Morococha; Beuchat et al. 2004; Catchpole et al. 2015) are also hosted by the Pucará Group. The $\mathrm{Zn}$ deposits of the Bongará district are considered to be stratabound MVT sulfide deposits, locally altered to nonsulfides after weathering processes (Fig. 1; Reid 2001; Basuki 2006; Basuki et al. 2008, Basuki and Spooner 2009; Wright 2010; Brophy 2012; Workman and Breede 2016; Arfè et al. 2017).

\section{Materials and methods}

Our studies were performed on 12 core samples from drillhole CR-13-08 (UTM latitude 9.374.355, longitude 831.039, Zone 17, Datum WGS 84) and on 20 samples from drillhole CR-188 (UTM latitude 9.374.369, longitude 831.043, Zone 17,
Datum WGS 84). Sampling was carried out at approximately meter intervals through the mineralized section of both cores (Appendix 1). The samples were crushed to $<5 \mathrm{~mm}$ and divided in two halves: the first half was used to prepare polished blocks for optical microscopy and SEM-EDS-WDS, whereas the remainder was further ground to produce powder for whole rock XRPD and chemical analyses. A quartered amount of $\sim 10 \mathrm{~g}$ of ground sample was used to prepare polished resin blocks ( $2 \mathrm{~cm}$ diameter), representative of the whole drillcore sample. Blocks were mounted in bicomponent epoxy resin (SpeciFix20), polished with alumina $\mathrm{Al}_{2} \mathrm{O}_{3}(0.3 \mu \mathrm{m})$ and diamond suspension $(1 \mu \mathrm{m})$. Blocks were carbon-coated prior to SEM and microprobe analysis.

$\mathrm{X}$-ray diffraction semi-quantitative analyses were performed using an X'Pert Powder diffractometer by PANalytical, at the Istituto Nazionale di Geofisica e Vulcanologia-Osservatorio Vesuviano (Napoli), with a high speed PIXcel detector, Ni-filtered, $\mathrm{CuK} \alpha$ radiation, pyrolytic graphite crystal monochromator, at $40 \mathrm{kV}$ and 
$40 \mathrm{~mA}$ in a $3-70^{\circ} 2 \theta$ range with $0.02^{\circ}$ steps at $8 \mathrm{~s} /$ step. Diffraction patterns were interpreted using the HighScore Plus software and JCPDS PDF-2 database. Mineral abundances have been determined as "wt $\%$ ranges," on the basis of the peak intensity ratio between mineral phases and the whole rock chemical analyses.

Whole rock chemical analyses were carried out in two different laboratories. Chemical analyses of the CR-13 drillcore samples of major ( $\mathrm{Zn}, \mathrm{Fe}, \mathrm{Mg}, \mathrm{Al}, \mathrm{K})$ and minor $(\mathrm{Cu}, \mathrm{Ni}, \mathrm{Co}$, As, $\mathrm{Cd}, \mathrm{Sb}, \mathrm{V}, \mathrm{Ba}, \mathrm{In}, \mathrm{Ga}, \mathrm{Ge}, \mathrm{Ag}$ ) elements were carried out at the Natural History Museum, London, UK. Approximately $50 \mathrm{mg}$ of powdered rock sample was dissolved in Savillex $60 \mathrm{ml}$ fluoropolymer vessels. $2-4.5 \mathrm{ml} \mathrm{HCl}$ and $0.05-$ $0.25 \mathrm{ml} \mathrm{HNO}_{3}$ were added to all samples and the mixture was shortly heated up to $70{ }^{\circ} \mathrm{C}$ and the temperature rose to $100{ }^{\circ} \mathrm{C}$ once the reaction had subsided. After samples were cooled down, $1 \mathrm{ml} \mathrm{HNO}, 1 \mathrm{ml} \mathrm{HClO}$, and $2 \mathrm{ml} \mathrm{HF}$ were added to each of them; the vessels were capped and heated overnight at $100^{\circ} \mathrm{C}$. Then the solutions were evaporated down at $150{ }^{\circ} \mathrm{C}$ and reconstructed in $50 \mathrm{ml}$ of ca. $0.6 \mathrm{M} \mathrm{HNO}_{3}$ with traces of $\mathrm{H}_{2} \mathrm{O}_{2}$. The solutions were analyzed by ICP-MS using an Agilent $7700 \times$ mass spectrometer. To minimize polyatomic interferences, the instrument was run with $5 \mathrm{ml} / \mathrm{min} \mathrm{He}$ (99.9995\% purity) in the collision-reaction octopole cell (CRC), as well as with no collision gas entering the CRC. Gallium $\left({ }^{71} \mathrm{Ga}\right)$ was determined in the "no gas" mode while all other elements were determined in the "He mode." To minimize the contamination of the instrument with high lead concentrations, the solutions were further diluted 100-fold with ca. $0.7 \mathrm{M} \mathrm{HNO}_{3}$. The instrument was calibrated using multi-element standards (Inorganic Ventures) typically with a four-point calibration with a correlation coefficient of $>$ 0.9999 . Accuracy was monitored by analyzing certified reference materials JLk-1 (lake sediment, GSJ) and SdAR-1 (modified river sediment, IAG) at the beginning and at the end of the run. All values were found to be within the uncertainty of the published data. The limits of quantification were calculated as ten times the standard deviation of $\mathrm{HNO}_{3}$ blank solution analyzed at least ten times during the run.

Whole rock chemical analyses of the CR-18 drillcore samples of major ( $\mathrm{Zn}, \mathrm{Fe}, \mathrm{Ca}, \mathrm{Mg}, \mathrm{Si}, \mathrm{Al}, \mathrm{Na}, \mathrm{K}, \mathrm{P}, \mathrm{Mn}$ ) and minor elements (Mo, $\mathrm{Cu}, \mathrm{Ni}, \mathrm{Co}, \mathrm{As}, \mathrm{Cd}, \mathrm{Sb}, \mathrm{V}, \mathrm{Ba}, \mathrm{In}$, $\mathrm{Ga}, \mathrm{Ge}, \mathrm{Ag}$ ) were carried out at Bureau Veritas Commodities Canada Ltd. (Vancouver, Canada), on identical powder splits to those used for XRPD analyses. In each case, $10 \mathrm{~g}$ of pulp was used for chemical analysis on the LF725 package (fusion/X-ray fluorescence spectroscopy-XRF). Samples with high Zn (greater than 24\%) were run for overlimits with the LF726 package. Minor elements were analyzed by using the AQ250-EXT (ultratrace aqua regia/ICP-AES and MS) package, except $\mathrm{Ga}$ and $\mathrm{Ge}$, which were analyzed using the GC204-Ge \& Ga package.
Scanning electron microscopy (SEM) and energy dispersion spectrometry (EDS) analyses were carried out by using a ZEISS EVO LS 15 scanning electron microscope (Natural History Museum, London, UK) at $20 \mathrm{kV}$, with $8.5 \mathrm{~mm}$ working distance and $3 \mathrm{nA}$ current mounting with X-Max detectors. A Co standard was used for the instrument calibration. Quantitative data sets of selected samples were obtained by wavelength dispersion spectrometry (WDS), using a Cameca SX100 electron microprobe operating at $20 \mathrm{kV}, 20 \mathrm{nA}$, and $10 \mu \mathrm{m}$ spot size (Natural History Museum, London, UK).

Laser ablation (LA)-ICP analyses were carried out using an ESI NWR193 UV $193 \mathrm{~nm}$ short pulse width (<4 ns) laser fitted with a TwoVol2 ablation cell and coupled to an Agilent $7700 \times$ quadrupole ICP-MS configured with dual external rotary pumps for enhanced sensitivity, located in the LODE laboratory-Natural History Museum (London). Ablated spots were $35-50 \mu \mathrm{m}$ in diameter, with a fluence of $3.5 \mathrm{~J} \mathrm{~cm}^{-2}$, fired at a frequency of $10 \mathrm{~Hz}$. The transport gas used was He at a flow rate of $0.51 \mathrm{~min}^{-1}$ mixed with $\mathrm{Ar}$ at a flow rate of $1.11 \mathrm{~min}^{-1}$; in a signal-smoothing device. The element menus and ICP-MS dwell time settings that were employed to obtain the compositions of the various minerals are listed in Appendix 1. Element ratios to an internal standard element $\left({ }^{29} \mathrm{Si}\right.$ for hemimorphite, ${ }^{57} \mathrm{Fe}$ for goethite and hematite, and ${ }^{66} \mathrm{Zn}$ for sphalerite) were determined by referencing background-corrected integrated intensities from mineral signals to the external calibration standard. This was NIST 612 for hemimorphite and GSD-1G glass (USGS) for goethite. External calibration with GSD-1G glass gave element concentrations for hemimorphite that were within $<5 \%( \pm)$ of the concentrations calculated with NIST 612. Following the procedure of Belissont et al. (2014), the polymetallic sulfide material MASS-1 was used for external calibration of sphalerite, using the Ge concentration of $57.8 \pm 2.6 \mathrm{ppm}$ (Dr. Stephen Wilson, personal communication, in Belissont et al. 2014). Absolute element concentrations were then calculated from internal standard element concentrations (predetermined by SEM-EDS) in the program ExLAM (Zachariáš and Wilkinson 2007). Limits of detection were set at the conventional $3 \sigma$ of the background signal variation (Longerich et al. 1996). GSD-1G, NIST 612, or NIST 610 were used as secondary standards; NIST 2782 and BC_28 (the in-house magnetite standard of Dare et al. 2014) were also monitored during Fe oxide or oxy-hydroxide analysis and NIST 2782 and NIST 610 for sphalerite analysis. Contamination of the phase of interest by inclusions (e.g., chalcopyrite in sphalerite; Mnoxy-hydroxides in goethite and hematite) or the crossing of grain boundaries was avoided by monitoring a number of nonformula elements associated with these contaminant phases. Time-resolved raw cps signals were meticulously screened and the longest "clean" integration intervals possible (up to $60 \mathrm{~s}$ of signal) were retained; analyses with significant contamination were discarded outright. Tuning was optimized 
for the whole mass range, and oxide formation (as represented by ${ }^{248} \mathrm{ThO} /{ }^{232} \mathrm{Th}$ ) and doubly-charged species formation (observed via ${ }^{22} \mathrm{Ca} /{ }^{44} \mathrm{Ca}$ ) were kept below $0.2 \%$. Two isotopes of $\mathrm{Ge}\left({ }^{72} \mathrm{Ge},{ }^{74} \mathrm{Ge}\right)$ were monitored to account for the possibility of a polyatomic interference of ${ }^{56} \mathrm{Fe}^{16} \mathrm{O}$ on ${ }^{72} \mathrm{Ge}$. In fact, there was good agreement between ${ }^{72} \mathrm{Ge}$ - and ${ }^{74} \mathrm{Ge}$-generated $\mathrm{Ge}$ concentrations $\left(R^{2}=0.99\right)$, and no correlation observed between calculated ${ }^{57} \mathrm{Fe}$ and ${ }^{72} \mathrm{Ge}$.

\section{Results}

\section{Mineralogy and petrography of the mineralization}

The mineralogical bulk compositions of the analyzed samples are reported in Appendix 1. In the CR-18 drillcore, it appears that the most abundant ore mineral is smithsonite (detected in 17 samples), followed by sphalerite and hemimorphite. Hemimorphite is ubiquitous, but it reaches abundant amounts ( $>60 \mathrm{wt} \%$ ) only in one sample (sample CR18-6). Sphalerite has concentrations between 5 and $20 \mathrm{wt} \%$, found in only three samples. Pyrite crystals are scattered in the dolomite host rock, but no galena was found. The main component of the host rock is dolomite, while quartz and minerals of the mica group have been detected locally. Goethite occurs in several samples, locally reaching $\sim 60 \mathrm{wt} \%$. The CR13 drillcore intercepts a single mineralized horizon, characterized by 20 to $40 \mathrm{wt} \%$ smithsonite in the upper part (sample CR13-2), and up to $60 \mathrm{wt} \%$ hemimorphite in the middle section (samples CR13-6 and CR13-7). Sphalerite and pyrite represent the only sulfide species occurring in the samples analyzed from this core. As in the CR18 drillcore, dolomite, quartz, and mica group minerals are the main constituents of the host rock in CR13. The maximum concentration of goethite $(\sim 60 \mathrm{wt} \%)$ was found in sample CR13-1.

Microscopic observation of the polished blocks showed that sphalerite and pyrite, as well as the dolomite host rock, are altered and replaced by other minerals: smithsonite and hemimorphite replace sphalerite and dolomite, whereas goethite replaces pyrite. In detail, it is possible to recognize two dolomite phases: the first dolomite is compositionally pure and microcrystalline (grain size $<0.5 \mathrm{~mm}$ ); the second dolomite is macrocrystalline (grain size up to $\sim 0.5 \mathrm{~cm}$ ), is in saddle form, and is chemically zoned with alternating $\mathrm{Fe}-\mathrm{Mn}$ rich bands (that contain up to $7 \mathrm{wt} \% \mathrm{Fe}$ and $1 \mathrm{wt} \%$ $\mathrm{Mn})$. Saddle dolomite creates a macroporosity, which is a common host for sphalerite and pyrite crystals (Fig. 2A). Sphalerite is always chemically zoned with alternating Ferich to $\mathrm{Fe}$-poor bands, containing between 5.25 and 12.89 wt\% Fe. Sphalerite also contains $\mathrm{Cd}$ ( $\max$ $0.9 \mathrm{wt} \%$ ) and does not show any inclusions of other minerals, like pyrite or evidence of "chalcopyrite disease."
Smithsonite and hemimorphite show two main textures, occurring either as replacement of dolomite and sphalerite or as euhedral-subhedral crystals in concretions. Replacive smithsonite is mainly developed along the growth planes of the dolomite crystals and around sphalerite (Fig. 2A and B). Concretionary smithsonite forms agglomerates of rounded crustiform particles or occurs as rare rhombohedral crystals in cavities (Fig. 2C). The two smithsonite phases are commonly impure: replacive smithsonite contains up to $\sim 2 \mathrm{wt} \% \mathrm{Fe}, \sim$ $1.5 \mathrm{wt} \% \mathrm{Mn}$, and $\sim 3 \mathrm{wt} \% \mathrm{Mg}$, whereas concretionary smithsonite contains up to $\sim 2 \mathrm{wt} \% \mathrm{Ca}$ and generally $<1 \mathrm{wt} \% \mathrm{Cd}$. Replacive hemimorphite shows textures analogous to replacive smithsonite (Fig. 2D), but in a few occurrences, it can be also found to directly replace smithsonite itself. The second generation of hemimorphite commonly occurs as fanshaped agglomerates of tabular crystals in cavities or veins, cutting dolomite, replacive smithsonite, and goethite (Fig. 2E). Hemimorphite in veins can be locally altered to Zn clays.

Goethite is found as alteration of pyrite. In fact, several cubic pseudomorphs of goethite commonly host pyrite remnants in the nucleus, but goethite can occur also as masses of porous botryoidal concretions. Replacive goethite is texturally associated with replacive smithsonite and hemimorphite. Concretionary goethite (Fig. 2F) is associated with the second generations of smithsonite and hemimorphite and is also displaced by hemimorphite veins. Rare Mn-hydroxides are scattered within the goethite mass. Pure goethite has never been observed: this mineral always contains up to $\sim 10 \mathrm{wt} \%$ $\mathrm{Zn}$ and up to $\sim 4 \mathrm{wt} \%$ Si: the lowest $\mathrm{Zn}$ and Si concentrations have been detected in the replacive goethite.

\section{Major and minor element concentrations}

Whole rock chemical analyses of the analyzed drillcore samples are shown in Table 1. In the mineralized samples, the $\mathrm{Zn}$ content is commonly over $15 \mathrm{wt} \%$ and can reach values higher than $50 \mathrm{wt} \%$. In particular, the highest $\mathrm{Zn}$ values are associated with the hemimorphite-rich layers of core CR13 (in the CR13-6 sample, a value of $53.03 \mathrm{wt} \% \mathrm{Zn}$ has been measured), containing more than $60 \mathrm{wt} \%$ of hemimorphite. In the most smithsonite-rich samples, the $\mathrm{Zn}$ value averages 35-40 wt\%. However, some Zn-bearing samples, e.g., CR13-1, contain $\mathrm{Zn}$-bearing goethite but lack conventional $\mathrm{Zn}$ minerals. Lead concentrations are generally low, being mostly at ppm levels and rarely reaching $\sim 1 \mathrm{wt} \% \mathrm{~Pb}$. On the contrary, the Fe content is high, being on average around $15 \mathrm{wt} \%$ with amounts variable between 0.5 and $58 \mathrm{wt} \% \mathrm{Fe}$. The highest Fe concentrations are associated with goethite; however, minor $\mathrm{Fe}$ amounts are also related to Fe-bearing saddle dolomite and Fe-rich sphalerite. Among the other metals, Mn is generally below $1 \mathrm{wt} \%, \mathrm{Cd}$ can reach maximum values of $1700 \mathrm{ppm}$, $\mathrm{Cu}$ and $\mathrm{Co}$ occur in trace amounts generally (although in 
Fig. 2 a Sphalerite and pyrite crystals texturally associated with Fe-bearing dolomite. Smithsonite altered the entire assemblage, precipitating between the dolomite crystals and in the fractures, and around sphalerite grains. Sample CR18-4. b Smithsonite directly replacing sphalerite and dolomite. Sample CR13-3. c Smithsonite concretions in cavity. Sample CR13-2. d Dolomite macrocrystals directly replaced along growth planes by hemimorphite and encrusted by goethite and by a second hemimorphite generation. Sample CR18-4. e Agglomerate of tabular crystals of hemimorphite. Sample CR13-6. f Goethite concretions texturally associated with smithsonite. Sample CR18-8. SEMEDS-BSE. Dol = dolomite; Gth = goethite; $\mathrm{Hm}=$ hemimorphite; $\mathrm{Sm}=$ smithsonite; $\mathrm{Sp}=$ sphalerite Py $=$ pyrite
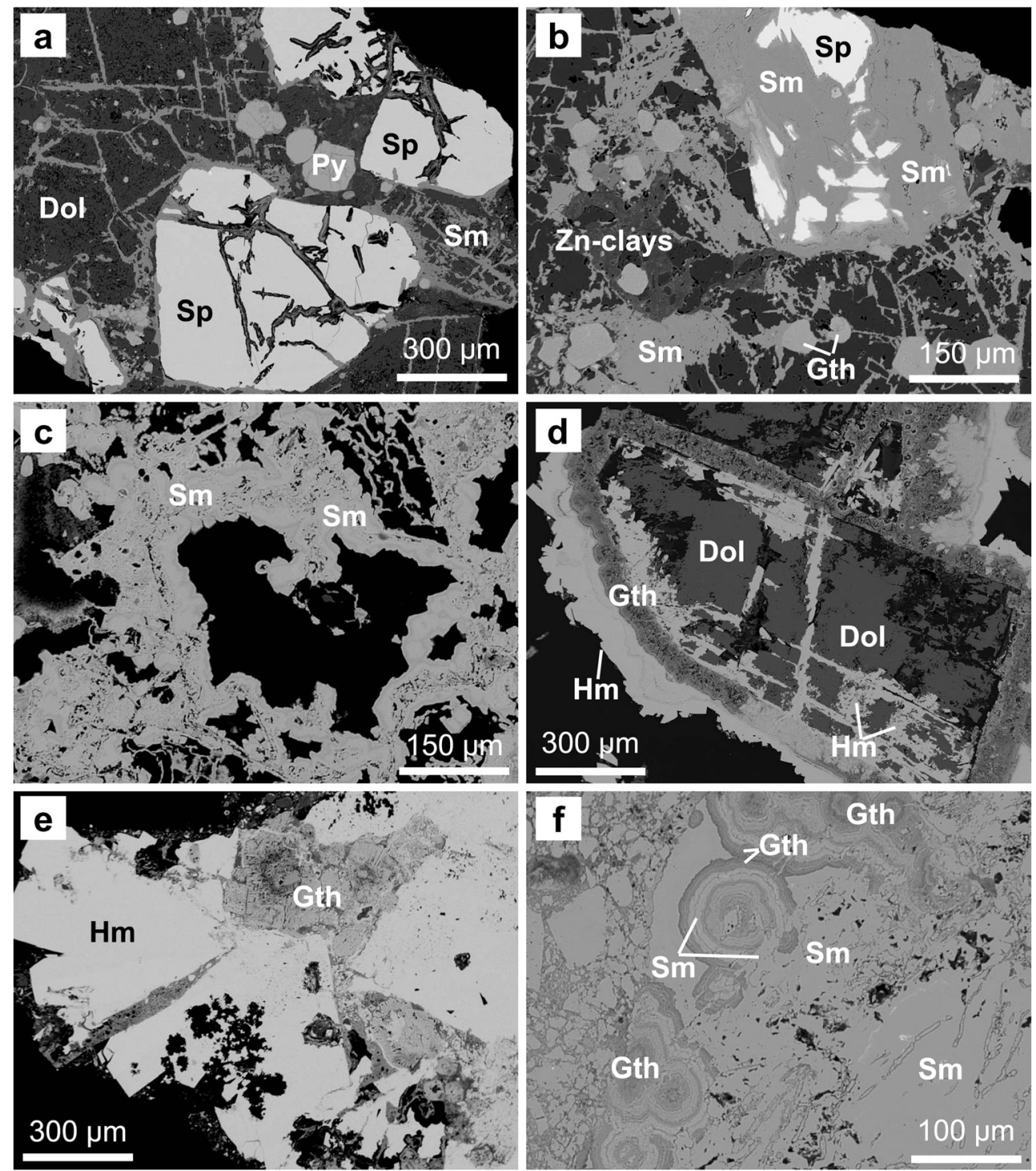

several samples, these elements reach concentrations of over $200 \mathrm{ppm}$ ), whereas Ni, As, Sb, V, In, and Ga are scarce. Other elements like Y and Co show average contents of around $70 \mathrm{ppm}$. It is therefore significant that Ge reaches bulk rock concentrations near to $150 \mathrm{ppm}$ and that these values are associated not only with sphalerite-containing samples but also with those containing abundant hemimorphite and goethite (Fig. 3).

\section{Trace element composition of selected mineral phases (LA-ICP-MS analysis)}

Laser ablation analyses were carried out on sphalerite, hemimorphite, and goethite (Appendix 2). Trace element compositions of sphalerite were measured in sample CR18-4 (Table 2, Appendix 2), where the mineral appeared to be particularly enriched in Fe (mean $8.19 \mathrm{wt} \%$ ). Manganese and $\mathrm{Pb}$ show low concentrations (max below $60 \mathrm{ppm}$ ), but other metals locally reach significant amounts: $\mathrm{Cd}$ mean $=$ $4600 \mathrm{ppm}, \max =8329 \mathrm{ppm} ; \mathrm{Cu}$ mean $=112 \mathrm{ppm}, \max =$ $228 \mathrm{ppm}$; and Co mean $=190 \mathrm{ppm}, \max =242 \mathrm{ppm}$. Germanium in sphalerite has a mean concentration of $142 \mathrm{ppm}$ and maximum levels of $386 \mathrm{ppm}$, and its concentration is inversely correlated with the Fe values (Fig. 4).

Hemimorphite was analyzed in three samples: CR13-4, CR13-6, and CR18-19 (Table 3, Appendix 2). In these samples, hemimorphite appears to have a constant trace element composition: contents of $\mathrm{Cd}$ (mean $=68$ to $193 \mathrm{ppm}, \max =$ 110 to $377 \mathrm{ppm}$ ) and $\mathrm{Ge}$ (mean $=39$ to $137 \mathrm{ppm}, \max =142$ to $258 \mathrm{ppm}$ ) have been detected, except in sample CR18-19, where very low $(\sim 60 \mathrm{ppm}) \mathrm{Fe}$ and $\mathrm{Al}$ concentrations have been measured.

Goethite was analyzed in two samples (Table 4, Appendix 2): CR13-1 and CR18-19. Here, it contains major amounts of Zn (4-5 wt\%) and minor amounts of $\mathrm{Al}$ and $\mathrm{Si}$ (generally $<1 \mathrm{wt} \%$ ). This mineral also contains several thousands of $\mathrm{ppm} \mathrm{Pb}$ and 


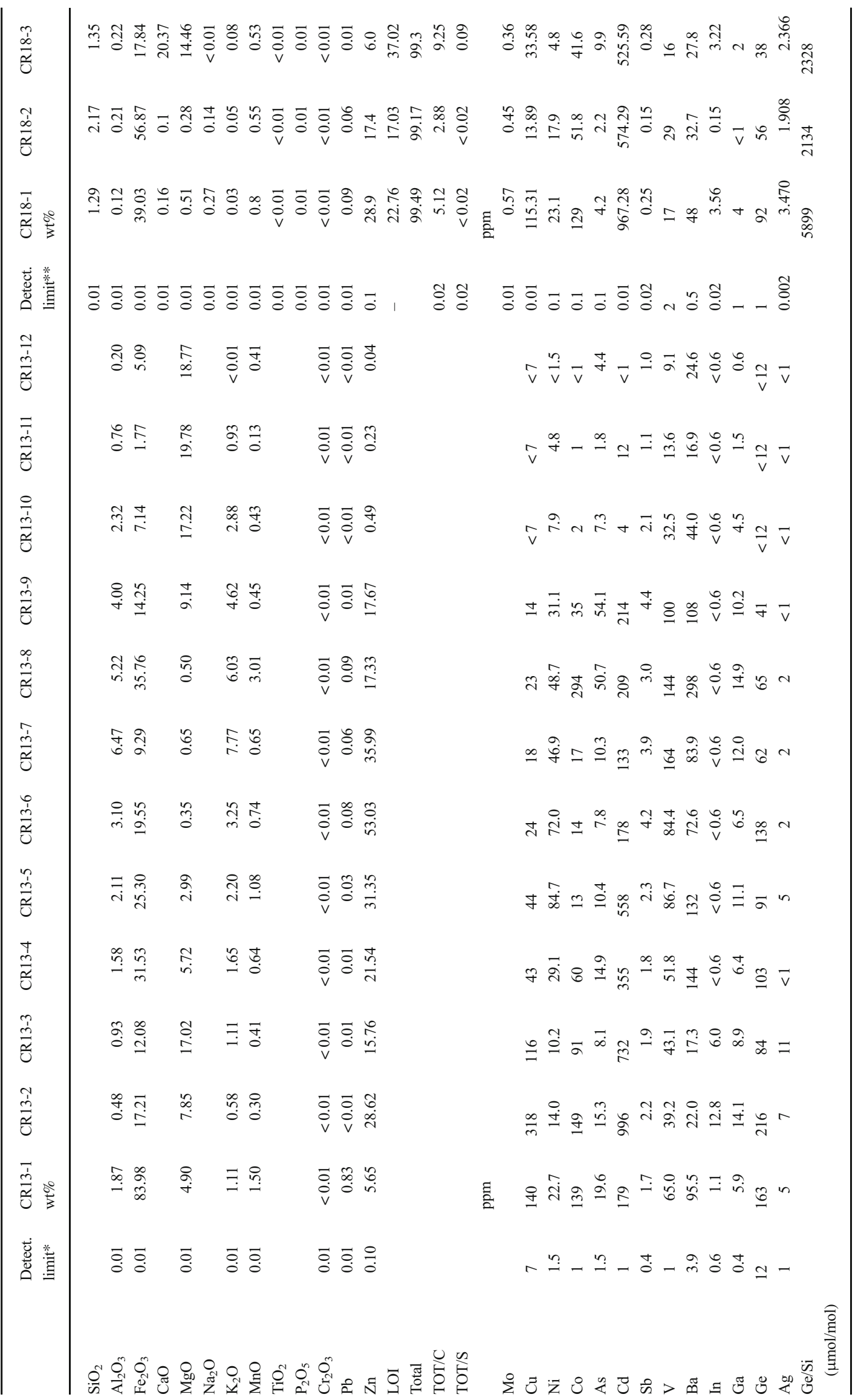




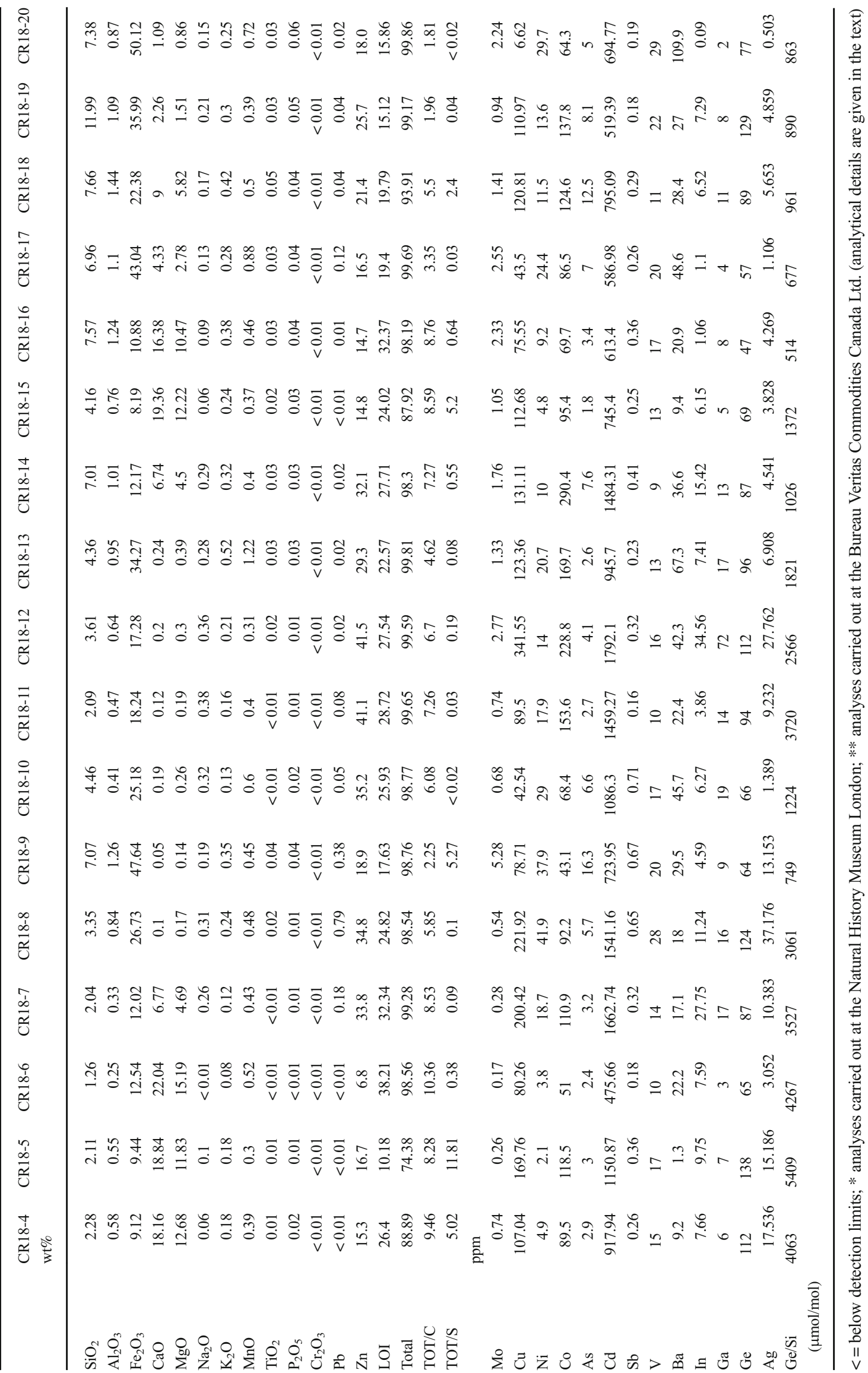




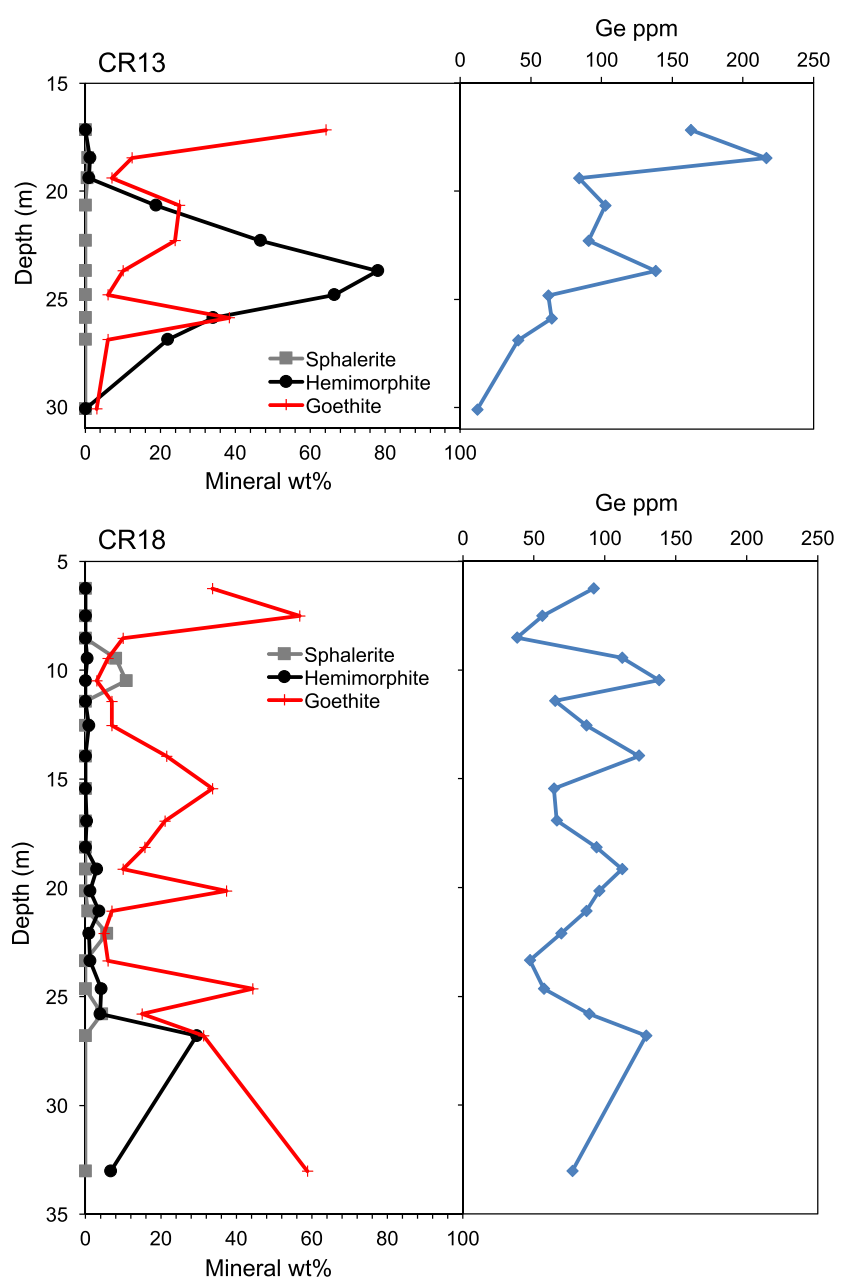

Fig. 3 Abundances of sphalerite, hemimorphite, and goethite estimated from XRD analysis (wt\%) vs. Ge concentration (ppm) in the analyzed samples

hundreds of ppm of $\mathrm{Mg}, \mathrm{Ca}, \mathrm{Co}, \mathrm{Cu}, \mathrm{Ge}, \mathrm{Y}, \mathrm{Cd}$, and $\mathrm{In}$, whereas the concentrations of other elements are below $100 \mathrm{ppm}$. Goethite in sample CR18-19 is characterized by concentrations of these elements significantly higher than in sample CR13-1. In the sample CR18-19, Ge concentration is on average $229 \mathrm{ppm}$, with maximum values of $511 \mathrm{ppm}$, whereas in sample CR13-1, the Ge levels are around $100 \mathrm{ppm}$. Indium is generally low in the measured samples, although CR18-19 has a maximum concentration of $191 \mathrm{ppm}$.

\section{Discussion}

Sphalerite is the most common host for Ge in sulfide ores (Höll et al. 2007; Cook et al. 2009; Melcher and Buchholz 2014; Frenzel et al. 2016), and for this reason, it is not a surprise that the sphalerite at Cristal hosts Ge. However, this study has revealed that the Cristal sphalerite contains anomalously high $\mathrm{Ge}$ amounts $($ mean $=142 \mathrm{ppm}$, $\max =$ $386 \mathrm{ppm})$. In addition, Cristal sphalerite is Fe-enriched $($ mean $=8.19 \mathrm{wt} \% \mathrm{Fe})$, with $\mathrm{Ge}$ and $\mathrm{Fe}$ concentrations inversely correlated, and the highest Ge values contained in the most $\mathrm{Fe}$-poor sphalerite. The negative $\mathrm{Ge}-\mathrm{Fe}$ correlation in sphalerite has been also observed in the lowtemperature vein-type deposit of Saint-Salvy in France (Belissont et al. 2014), where the $\mathrm{Zn}$ sulfide is characterized by $\mathrm{Fe}$ contents varying between 1.2 and $4.2 \mathrm{wt} \% \mathrm{Fe}$, with up to $2576 \mathrm{ppm}$ Ge only contained in $\mathrm{Fe}$-poor sphalerite. Ge-Fe-bearing sphalerites have been observed rarely in other deposits. The Fankou deposit in China, considered a low-temperature SHMS or MVT deposit (Song 1984; Frenzel et al. 2016), has sphalerite containing 3.8 to $6.2 \mathrm{wt} \% \mathrm{Fe}$ and 110 to $80 \mathrm{ppm} \mathrm{Ge}$ (Song 1984; Song and Tan 1996). The Tres Marias Mine in Mexico, considered a low-temperature MVT ore (Cook et al. 2009) or a magmatic-related carbonate-replacement deposit (CRD; Ostendorf et al. 2017), shows sphalerite containing $10 \mathrm{wt} \% \mathrm{Fe}$ and $\sim 960 \mathrm{ppm}$ Ge on average (Saini-Eidukat et al. 2009). Ge-Fe-bearing sphalerite ( $\sim 5 \mathrm{wt} \% \mathrm{Fe}$ and $\sim$ $200 \mathrm{ppm} \mathrm{Ge}$ ), texturally associated with discrete Gesulfides (e.g., renierite), has been also detected in the pipe-like Kipushi deposit (Democratic Republic of Congo), where sulfides are interpreted to have formed at temperatures $>300{ }^{\circ} \mathrm{C}$ (Schneider et al. 2007).

Table 2 Major (WDS) and trace (LA-ICP-MS) element composition of sphalerite

\begin{tabular}{|c|c|c|c|c|c|c|c|c|c|c|c|c|c|c|c|c|c|}
\hline Sample & & $\begin{array}{l}\mathrm{S} \\
\mathrm{wt} \%\end{array}$ & $\mathrm{Fe}$ & $\mathrm{Zn}$ & $\mathrm{Cd}$ & $\begin{array}{l}\mathrm{Mn} \\
\mathrm{ppm}\end{array}$ & Co & $\mathrm{Ni}$ & $\mathrm{Cu}$ & $\mathrm{Ga}$ & $\mathrm{Ge}^{* *}$ & $\mathrm{Ag}$ & $\mathrm{Cd}$ & In & Sn & $\mathrm{Sb}$ & $\mathrm{Pb}$ \\
\hline \multirow{6}{*}{$\begin{array}{l}\text { CR18-4 } \\
n=20\end{array}$} & Mean & 33.30 & 8.19 & 58.2 & 0.52 & 18.9 & 189.5 & 0.2 & 111.6 & 1.3 & 142.4 & 38.4 & 4600.4 & 2.4 & 1.0 & 0.2 & 8.1 \\
\hline & Dev. Stand. & 0.27 & 2.27 & 2.4 & 0.26 & 9.8 & 38.6 & 0.1 & 67.8 & 2.0 & 121.0 & 46.2 & 1872.0 & 8.3 & 0.4 & 0.3 & 6.3 \\
\hline & Maximum & 33.70 & 12.89 & 61.9 & 0.94 & 39.8 & 242.0 & 0.4 & 228.7 & 6.6 & 386.3 & 133.8 & 8428.9 & 36.7 & 2.1 & 0.8 & 22.2 \\
\hline & Minimum & 32.68 & 5.25 & 54.4 & 0.19 & 7.6 & 129.1 & 0.1 & 40.3 & 0.02 & 0.3 & 1.2 & 1938.8 & 0.005 & 0.6 & 0.02 & 0.1 \\
\hline & Median & 33.29 & 8.00 & 59.1 & 0.49 & 16.5 & 180.8 & 0.2 & 79.6 & 0.1 & 130.7 & 12.4 & 4923.3 & 0.02 & 0.9 & 0.1 & 7.0 \\
\hline & Avg. LOD. & 0.04 & 0.05 & 0.2 & 0.08 & 0.1 & 0.01 & 0.03 & 0.2 & 0.01 & 0.1 & 0.004 & 0.8 & 0.005 & 0.3 & 0.02 & 0.02 \\
\hline
\end{tabular}

$*$ LA-ICP-MS analyses: Internal standard $=$ Zn; External standard $=$ MASS-1; $* *$ Ge value for external calibration $=57.8$ ppm $($ Belissont et al. 2014); Avg. LOD = average limit of detection 
Fig. 4 Fe wt\% (WDS) vs Ge ppm (LA-ICP-MS) concentrations in sphalerite

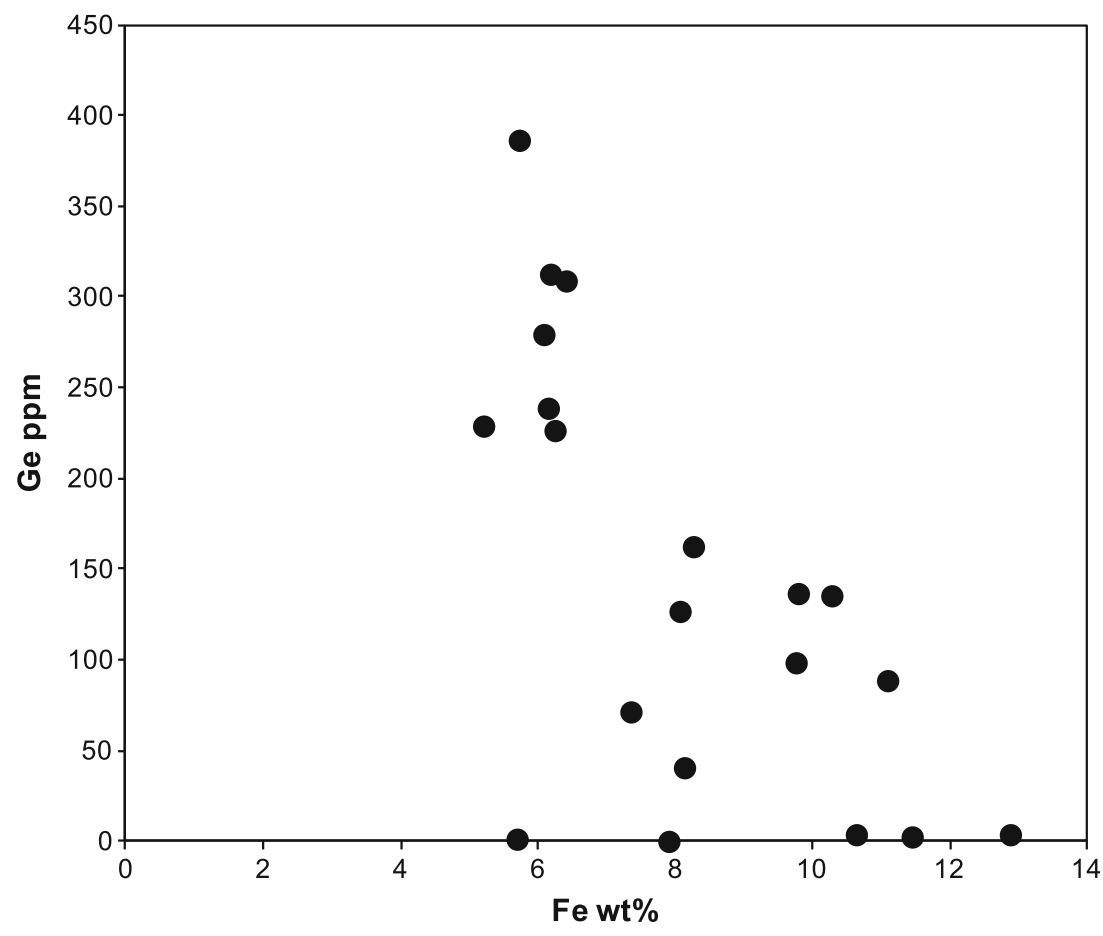

The metallogeny of the Cristal area (Brophy 2012) and the strong similarity between the textural characteristics of the Río Cristal ores and those of the other deposits in the same region, which have been classified as MVT (Basuki et al. 2008; Basuki and Spooner 2009), suggest that also the Cristal sulfides may have originated from MVT fluids. However, it is evident that the Cristal sphalerite is unusually Fe-rich for a typical MVT deposits (Frenzel et al. 2016). Following the equation of Frenzel et al. (2016),

$\mathrm{PC}^{*}=\ln \left(\frac{C_{\mathrm{Ga}}^{0.22} \cdot C_{\mathrm{Ge}}^{0.22}}{C_{\mathrm{Fe}}^{0.37} \cdot C_{\mathrm{Mn}}^{0.20} \cdot C_{I n}^{0.11}}\right)$

Table 3 Major (WDS) and trace (LA-ICP-MS) element composition of hemimorphite

\begin{tabular}{|c|c|c|c|c|c|c|c|c|c|c|c|c|c|c|c|c|c|}
\hline Sample & & $\begin{array}{l}\mathrm{Si} \\
\mathrm{wt} \%\end{array}$ & $\mathrm{Zn}$ & $\begin{array}{l}\text { B } \\
\text { ppm }\end{array}$ & $\mathrm{Na}$ & $\mathrm{Mg}$ & $\mathrm{Al}$ & $\mathrm{Sc}$ & $\mathrm{Ti}$ & $\mathrm{V}$ & $\mathrm{Fe}$ & $\mathrm{Cu}$ & $\mathrm{Ga}$ & $\mathrm{Ge}$ & $\mathrm{Cd}$ & $\mathrm{Pb}$ & $\begin{array}{l}\mathrm{Ge} / \mathrm{Si} \\
\mu \mathrm{mol} / \mathrm{mol}\end{array}$ \\
\hline \multirow{6}{*}{$\begin{array}{l}\text { CR13-4 } \\
n=13\end{array}$} & Mean & 11.6 & 54.5 & 3 & - & 0.2 & 4.0 & 0.3 & 0.5 & 0.1 & 5 & 0.2 & - & 137.3 & 68.0 & 0.3 & \multirow[t]{6}{*}{457} \\
\hline & Dev. Stand. & 0.1 & 0.6 & 2 & - & 0.1 & 2.9 & 0.2 & 0.1 & 0.1 & 3 & 0.0 & - & 90.9 & 20.7 & 0.1 & \\
\hline & Maximum & 11.8 & 55.4 & 7 & - & 0.4 & 8.7 & 1.0 & 0.6 & 0.4 & 7 & 0.3 & - & 247.4 & 109.8 & 0.5 & \\
\hline & Minimum & 11.4 & 53.5 & 1 & - & 0.1 & 0.8 & 0.2 & 0.4 & 0.0 & 3 & 0.2 & - & 5.2 & 36.9 & 0.1 & \\
\hline & Median & 11.6 & 54.5 & 2 & - & 0.2 & 2.8 & 0.3 & 0.4 & 0.1 & 5 & 0.2 & - & 164.3 & 63.0 & 0.2 & \\
\hline & Avg. LOD & 0.2 & 0.7 & 1 & 2 & 0.1 & 0.6 & 0.07 & 0.4 & 0.02 & 3 & 0.2 & 0.03 & 0.1 & 0.6 & 0.04 & \\
\hline \multirow{6}{*}{$\begin{array}{l}\text { CR13-6 } \\
n=24\end{array}$} & Mean & 11.7 & 54.2 & 3 & - & 0.4 & 4.9 & 0.9 & - & 0.9 & 6 & 0.2 & - & 83.0 & 110.0 & 0.6 & \multirow[t]{6}{*}{275} \\
\hline & Dev. Stand. & 0.1 & 0.4 & 1 & - & 0.5 & 4.1 & 0.9 & - & 2.5 & 1 & 0.0 & - & 70.1 & 30.8 & 0.4 & \\
\hline & Maximum & 11.8 & 54.9 & 5 & - & 1.3 & 15.9 & 4.8 & - & 11.6 & 7 & 0.3 & - & 258.0 & 192.8 & 2.1 & \\
\hline & Minimum & 11.5 & 53.6 & 2 & - & 0.1 & 0.4 & 0.2 & - & 0.1 & 5 & 0.2 & - & 3.4 & 69.1 & 0.3 & \\
\hline & Median & 11.7 & 54.1 & 2 & - & 0.2 & 3.9 & 0.7 & - & 0.4 & 7 & 0.2 & - & 54.9 & 103.9 & 0.5 & \\
\hline & Avg. LOD & 0.2 & 0.7 & 2 & 2 & 0.1 & 0.4 & 0.09 & 0.5 & 0.03 & 3 & 0.2 & 0.03 & 0.2 & 0.7 & 0.06 & \\
\hline \multirow{6}{*}{$\begin{array}{l}\text { CR18-19 } \\
n=21\end{array}$} & Mean & 11.6 & 54.4 & 4 & - & 0.8 & 9.8 & 0.4 & 0.7 & 0.1 & 21 & 0.2 & 0.02 & 38.9 & 192.6 & 0.7 & \multirow[t]{6}{*}{129} \\
\hline & Dev. Stand. & 0.1 & 0.5 & 5 & - & 1.1 & 16.3 & 0.1 & 0.5 & 0.1 & 21 & 0.1 & 0.01 & 37.0 & 73.1 & 0.3 & \\
\hline & Maximum & 11.8 & 55.5 & 13 & - & 4.8 & 59.1 & 0.6 & 1.5 & 0.6 & 61 & 0.4 & 0.03 & 142.0 & 377.4 & 1.2 & \\
\hline & Minimum & 11.4 & 53.6 & 1 & - & 0.1 & 0.7 & 0.2 & 0.5 & 0.0 & 3 & 0.2 & 0.02 & 2.2 & 91.9 & 0.3 & \\
\hline & Median & 11.7 & 54.3 & 2 & - & 0.4 & 2.1 & 0.4 & 0.5 & 0.1 & 16 & 0.2 & 0.02 & 25.4 & 176.8 & 0.6 & \\
\hline & Avg. LOD & 0.2 & 0.7 & 2 & 2 & 0.1 & 0.6 & 0.08 & 0.5 & 0.02 & 3 & 0.2 & 0.03 & 0.2 & 0.8 & 0.07 & \\
\hline
\end{tabular}

*LA-ICP-MS analyses: Internal standard = Si; External standard = LODE_NIST 612; Avg. LOD = average limit of detection 
(with concentrations of $\mathrm{Ge}, \mathrm{Ga}, \mathrm{Mn}$, and In in ppm and $\mathrm{Fe}$ in $\mathrm{wt} \%$ ) and the empirical relationship between the PC $1 *$ and the homogenization temperature of fluid inclusions in sphalerite, the $\mathrm{Zn}$ sulfide chemistry can be used to discriminate between MVT and high-temperature hydrothermal replacement-HTHR deposits. Using this equation, we calculated a PC $1 *$ value of -0.32 for the Cristal sphalerite, which falls in the interval where the PC $1^{*}$ values of MVT and HTHR deposits overlap (see Fig. 7 in Frenzel et al. 2016). Moreover, by using the GGIMFis geothermometergeothermometer for $\mathrm{Ga}, \mathrm{Ge}, \mathrm{In}, \mathrm{Mn}$, and $\mathrm{Fe}$ in sphaleritealso proposed by Frenzel et al. (2016):

$T\left({ }^{\circ} \mathrm{C}\right)=-(54.4 \pm 7.3) \cdot \mathrm{PC} 1^{*}+(208 \pm 10)$

we obtained a $T_{\text {GGIMFis }}$ of $225 \pm 50{ }^{\circ} \mathrm{C}$, which indicates a possible homogenization temperature for the Cristal sphalerite slightly higher than temperatures of other MVT deposits in the area (measured $T_{\mathrm{h}}$ between 93 and $147^{\circ} \mathrm{C}$ for the Florida Canyon sphalerite and measured $T_{\mathrm{h}}$ between 136 and $171{ }^{\circ} \mathrm{C}$ for the Florcita sphalerite; Basuki and Spooner 2009). These temperatures are also higher than the average formation temperatures of typical MVT deposits (Leach et al. 2005; Frenzel et al. 2016 and references therein). This information, coupled with the mineral assemblage of the nearby Mina Grande nonsulfide $\mathrm{Zn}$ deposit, where Arfè et al. (2017) also detected minerals like Mn-oxy-hydroxides and $\mathrm{Zn}$-bearing micas, suggests a possible polymetallic nature to the original sulfide mineralization or could indicate a hightemperature character of the MVT protore at Río Cristal.

The simple comparison between the measured Ge grades and the mineralogy of the samples has indicated that Ge could be partly hosted in atypical Ge-bearing minerals. The LA-ICP-MS analyses have demonstrated high Ge concentrations in hemimorphite and goethite. Hydrosilicates and goethite have been found to be enriched in Ge only in the oxidation zones overlying exceptionally Ge-rich sulfide ores (Höll et al. 2007). Fe hydroxides at Tsumeb revealed a content of up to $2.5 \mathrm{wt} \% \mathrm{Ge}$ (Melcher 2003), whereas goethite in the Apex Mine was found to host up to 5310 ppm Ge (Bernstein 1985, 1986; Dutrizac et al. 1986). Only the hemimorphite of Raibl-Cave del Predil (Italy) and Bleiberg (Austria) is enriched with up to $1000 \mathrm{ppm} \mathrm{Ge}$ (Schroll 1953; Brigo and Cerrato 1994). Germanium concentrations measured at Cristal in hemimorphite $($ mean $=39$ and $137 \mathrm{ppm}, \max =142$ and $258 \mathrm{ppm}$ ) and goethite (mean $=100$ and $229 \mathrm{ppm}, \max =$ $511 \mathrm{ppm}$ ) are significantly lower than the maximum $\mathrm{Ge}$ amounts measured at Tsumeb, Apex, Cave del Predil/ Raibl, and Bleiberg. Germanium concentration in Cristal goethite and hemimorphite is on average at the same levels found in the protore sphalerite; moreover, the Ge levels in 
the bulk rock analyses of the sphalerite-bearing samples and of the oxidized samples are basically the same, indicating that Ge has not been leached and dispersed after the alteration of Ge-bearing sphalerite.

The occurrence of Ge in hemimorphite and goethite offers clues to the geochemical conditions prevailing at the time of the supergene oxidation of the primary sulfides and subsequent incorporation of Ge into the oxidized minerals. Several studies (e.g., Pokrovski and Schott 1998a, b) have shown that in oxidized natural fluids, with the exception of seawater and organicrich surficial waters, Ge occurs as tetravalent Ge species and, like $\mathrm{Si}$, is present as hydroxide complexes $\left(\mathrm{Ge}(\mathrm{OH})_{4}{ }^{\circ}\right.$ (aq) and $\mathrm{Si}$ $(\mathrm{OH})_{4}{ }_{(\text {aq })}$ ). At $25^{\circ} \mathrm{C}$ and varying $\mathrm{pH}, \mathrm{Ge}$ and $\mathrm{Si}$ hydroxide complexes have a similar distribution as a function of $\mathrm{pH}$, both $\mathrm{GeO}_{2 \text { (tetr) }}$ and amorphous silica being highly soluble above $\mathrm{pH}$ $\sim 7$ (at $\mathrm{pH}=10$ to $11: C_{\mathrm{Ge}}=5$ to $30 \mathrm{mg} / \mathrm{L}, C_{\mathrm{Si}}=150$ to $>$ $500 \mathrm{mg} / \mathrm{L}$ ) and less soluble below $\mathrm{pH} \sim 7$ (at $\mathrm{pH}=5$ to 7 : $C_{\mathrm{Ge}}=0.50$ to $0.70 \mathrm{mg} / \mathrm{L}, C_{\mathrm{Si}}=50$ to $60 \mathrm{mg} / \mathrm{L}$; Pokrovski and Schott 1998a, b). At the same temperature and $\mathrm{pH}$, amorphous

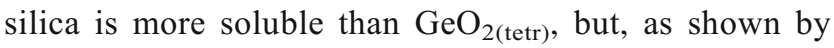
Pokrovski and Schott (1998b), aqueous Ge speciation can be considerably affected by the presence of humic acids, which preferentially form complexes with $\mathrm{Ge}$ and not with $\mathrm{Si}$, increasing the $\mathrm{Ge} / \mathrm{Si}$ molar ratio in the aqueous fluids. These different geochemical behaviors are invoked for explaining the $\mathrm{Ge}-\mathrm{Si}$ fractionation during weathering of silicates, which normally produce soils where $\mathrm{Ge} / \mathrm{Si}$ molar ratios are higher than in original parent rocks (Kurtz et al. 2002; Lugolobi et al. 2010; Mortlock and Froelich 1987). For example, Kurtz et al. (2002) have shown that on the Hawaiian Islands, soils developed on intensely weathered basalts have bulk soil Ge/Si ratios two to ten times higher than fresh basalt (e.g., 10 to $25 \mu \mathrm{mol} /$ mol vs. $2.5 \mu \mathrm{mol} / \mathrm{mol}$ ). Similarly, Scribner et al. (2006) suggested that $\mathrm{Ge} / \mathrm{Si}$ fractionation during weathering was mostly controlled by the partitioning of Ge into secondary clay minerals (e.g., kaolinite), rather than retention in soil Fe oxy-hydroxides. The Cristal case is different from the mentioned examples, because (i) the Ge source was not an unaltered bedrock (e.g., a basalt containing $<2 \mathrm{ppm} \mathrm{Ge}$ ), but as reported above, a Ge-rich sphalerite (mean Ge is $142 \mathrm{ppm}$ ), (ii) the Ge/Si ratios in the bulk samples are enormously higher than those measured in normal soils (e.g., $\sim 10^{3} \mu \mathrm{mol} / \mathrm{mol}$ - see Table $1-$ vs. 10 to $25 \mu \mathrm{mol} / \mathrm{mol}$ - Kurtz et al. 2002), (iii) the most abundant Gebearing minerals are hemimorphite and goethite (clays are negligible at Cristal), and (iv) the $\mathrm{Ge} / \mathrm{Si}$ ratios in these minerals are around $\sim 10^{2}-10^{3} \mu \mathrm{mol} / \mathrm{mol}$ (Tables 3 and 4 ). Moreover, in the Cristal case, a preferential capture of $\mathrm{Ge}$ in Fe hydroxides is supported by evidence that goethite is, on average, richer in $\mathrm{Ge}$ than hemimorphite. Pokrovsky et al. (2006) conducted experimental studies on Ge adsorption on goethite and Ge coprecipitation with $\mathrm{Fe}$ hydroxides at $25^{\circ} \mathrm{C}$. These studies have shown that $\mathrm{Ge}$ is adsorbed as $>\mathrm{FeH}_{3} \mathrm{GeO}_{4}{ }^{0}$ surface complexes, where Ge is tetrahedrally coordinated. The authors also reported that the percentage of adsorbed Ge increases with $\mathrm{pH}$ up to $\mathrm{pH} \leq 9$, reaches a maximum at $\mathrm{pH} \sim 9$, and slightly decreases when $\mathrm{pH}$ is further increased to 11. Co-precipitation of $\mathrm{Ge}$ with $\mathrm{Fe}$-oxy-hydroxides, formed during $\mathrm{Fe}^{2+}$ oxidation by atmospheric oxygen or by $\mathrm{Fe}^{3+}$ hydrolysis in neutral solutions, results in $\mathrm{Ge}$ incorporations in the mineral with $\mathrm{Ge} / \mathrm{Fe}$ molar ratio proportional to that in the initial solution with maximum $\mathrm{Ge} / \mathrm{Fe}$ molar ratios close to 0.5 . In the Fe hydroxide crystal structure, Ge can be octahedrally coordinated with oxygen (Pokrovsky et al. 2006). The co-precipitation of Ge with Feoxy-hydroxides is favored by the increase of $\mathrm{pH}$, but in the $\mathrm{pH}$ range from 5 to 10 (typical of natural waters), the effect of $\mathrm{pH}$ on Ge co-precipitation is weak (Pokrovsky et al. 2006). Assuming that Ge occurs in the hemimorphite structure in substitution for $\mathrm{Si}$ in the tetrahedral sites (in analogy with $\mathrm{Si}-\mathrm{Ge}$ substitution observed in natural willemite; Saini-Eidukat et al. 2016) and considering instead that Ge can occur with two different types of polyhedral coordination in the Fe hydroxide crystal lattice, it is reasonable to suppose that Ge is more favorably incorporated into $\mathrm{Fe}$ hydroxides than into $\mathrm{Zn}$ hydrosilicates. However, considering that hemimorphite is stable at $25^{\circ} \mathrm{C}$ at $\mathrm{pH}<7$ (Takahashi 1960) and that in the same conditions Ge compounds have the minimum solubility (Pokrovski and Schott 1998a; Wood and Samson 2006), it is reasonable to suppose that when $\mathrm{Ge}$ is leached from original Ge-bearing sphalerite during weathering and the environmental conditions favor hemimorphite stability, Ge can be incorporated into hemimorphite.

Goethite and hemimorphite are minerals typical of supergene nonsulfide $\mathrm{Zn}$ deposits, but their abundance depends on the availability of Fe and silica. In particular, it is well known that under humid-tropical climate, silica can be more efficiently leached from silicate rocks than $\mathrm{Al}$ or Fe (White and Blum 1995; Retallack 2010). Considering the analogy between the Cristal nonsulfide mineralization and other similar prospects in the Bongará area (e.g., Mina Grande, Arfè et al. 2017), we assume that the supergene alteration at Cristal likely occurred under warm-humid climate and high precipitation rates. These specific conditions, together with the presence of weathered sulfides creating an acid environment, probably increased the Si availability and favored the formation of hemimorphite over smithsonite, enhancing the possibility for stable Gebearing secondary phases. At the same time, Fe has been residually enriched in the more gossanous parts of the orebody, producing the mentioned phenomenon of Ge incorporation into $\mathrm{Fe}$ hydroxides.

\section{Conclusions}

In the partly weathered core samples from the Cristal orebody, Ge occurs with bulk rock concentrations locally higher than 
the Ge amounts found in mined deposits where Ge is successfully recovered as by-product of $\mathrm{Zn}$ extraction. At Cristal, Ge was detected in sphalerite, hemimorphite, and goethite. This is significant, since even though the occurrence of Ge in silicates and goethite has been already predicted from theoretical studies, this element has been seldom detected in supergene nonsulfide deposits. Sphalerite at Cristal contains anomalously high Ge concentrations (mean $=142 \mathrm{ppm}, \max =386 \mathrm{ppm}$ ), and it is unusually Fe-rich for typical MVT deposits (Frenzel et al. 2016). By using the geothermometer proposed by Frenzel et al. (2016), we obtained a homogenization $T_{\text {GGIMFis }}$ of $225 \pm 50^{\circ} \mathrm{C}$, which is on average slightly higher than temperatures of other MVT deposits of the area (measured $T_{\mathrm{h}}$ between 93 and $147^{\circ} \mathrm{C}$ for the Florida Canyon sphalerite and measured $T_{\mathrm{h}}$ between 136 and $171^{\circ} \mathrm{C}$ for the Florcita sphalerite; Basuki and Spooner 2009) and also higher than average formation temperatures compared to typical MVT deposits (Leach et al. 2005; Frenzel et al. 2016 and references therein). Germanium concentrations measured in hemimorphite (means ranging from 39 to $137 \mathrm{ppm}$, with a maximum measured value of $258 \mathrm{ppm}$ ) and goethite (means ranging from 100 to $229 \mathrm{ppm}$, with a maximum measured value of $511 \mathrm{ppm}$ ) are on average at the same levels than those found in sphalerite, and the Ge amounts in the bulk rock analyses of the sphalerite-bearing samples and of the oxidized samples are basically the same. A persistent warm-humid climate in the area resulted in the development of an oxidation zone, which favored the formation of abundant $\mathrm{Zn}$ hydrosilicates and $\mathrm{Fe}$ hydroxides, both able to incorporate Ge in their crystal structure. This has resulted in the retention of $\mathrm{Ge}$ in the supergene profile and has prevented Ge from dispersing during the weathering of the Ge-bearing sulfides, in agreement with previous studies on weathering of Ge (e.g., Kurtz et al. 2002; Mortlock and Froelich 1987). The occurrence of high Ge concentrations makes the Cristal nonsulfide deposit a proxy for future research on Ge behavior in supergene settings. We are currently conducting studies to test the viability of economic Ge recovery from hemimorphite and goethite, as by-product of $\mathrm{Zn}$ extraction from the nonsulfide ores, which may represent a neglected future source of the metal.

Acknowledgments N. Mondillo and co-authors are grateful to the Compañia Minera Pilar del Amazonas (C. Ushela) for introducing them to the Bongará mineralization and to Zinc One Resources Inc. for allowing publication. The authors are greatly indebted to Prof. L. Fontboté, to an anonymous reviewer, and to the associate editor Prof F. Melcher for their comments and suggestions, which helped to significantly improve the manuscript. The authors are also grateful to the staff of the Core Research Laboratories at the NHM (London) for the support during the analytical work.

Funding information This project has received funding from the European Union's Horizon 2020 research and innovation program, by a Marie Skłodowska-Curie Individual Fellowship (Project Number
660885) awarded to R. Herrington, supporting the fellowship of N. Mondillo. Fieldwork was also funded by a Student Research Grant (Project SRG_15-40) from the Society of Economic Geologists Canada Foundation (SEGCF) to G. Arfè.

Open Access This article is distributed under the terms of the Creative Commons Attribution 4.0 International License (http:// creativecommons.org/licenses/by/4.0/), which permits unrestricted use, distribution, and reproduction in any medium, provided you give appropriate credit to the original author(s) and the source, provide a link to the Creative Commons license, and indicate if changes were made.

\section{References}

Arfè G, Mondillo N, Boni M, Balassone G, Joachimski M, Mormone A, Di Palma T (2017) The karst hosted Mina Grande nonsulfide zinc deposit, Bongará district (Amazonas region, Peru). Econ Geol 112(5):1089-1110. https://doi.org/10.5382/econgeo.2017.4503

Basuki NI (2006) Post-early Cretaceous MVT Zn-Pb mineralisation, Bongara area, northern Peru: fluid characteristics and constraints on deposition mechanisms. Unpublished Ph.D. thesis, University of Toronto, p 318

Basuki NI, Spooner ETC (2009) Post-early Cretaceous Mississippi Valley type $\mathrm{Zn}-\mathrm{Pb}$ mineralization in the Bongará area, northern Peru: fluid evolution and paleo-flow from fluid inclusions evidence. Explor Min Geol 18(1-4):25-39. https://doi.org/10.2113/gsemg.18. $1-4.25$

Basuki NI, Taylor BE, Spooner ETC (2008) Sulfur isotope evidence for thermochemical reduction of dissolved sulfate in Mississippi Valleytype zinc-lead mineralization, Bongara area, northern Peru. Econ Geol 103(4):783-799. https://doi.org/10.2113/gsecongeo.103.4.783

Baumgartner R, Fontboté L (2008) Mineral zoning and geochemistry of epithermal polymetallic $\mathrm{Zn}-\mathrm{Pb}-\mathrm{Ag}-\mathrm{Cu}$-Bi mineralization at Cerro de Pasco, Peru. Econ Geol 103(3):493-537. https://doi.org/10.2113/ gsecongeo.103.3.493

Baumgartner R, Fontboté L, Spikings R, Ovtcharova M, Schaltegger U, Schneider J, Page L, Gutjahr M (2009) Bracketing the age of magmatic-hydrothermal activity at the Cerro de Pasco epithermal polymetallic deposit, Central Peru: a U-Pb and 40Ar/39Ar Study. Econ Geol 104(4):479-504. https://doi.org/10.2113/gsecongeo.104. 4.479

Belissont R, Boiron M-C, Luais B, Cathelineau M (2014) LA-ICP-MS analyses of minor and trace elements and bulk Ge isotopes in zoned Ge-rich sphalerites from the Noailhac-Saint-Salvy deposit (France) insights into incorporation mechanisms and ore deposition processes. Geochim Cosmochim Acta 126:18-540

Bendezú R, Fontboté L (2009) Cordilleran epithermal Cu-Zn-Pb-(Au$\mathrm{Ag})$ mineralization in the Colquijirca district, central Peru: depositscale mineralogical patterns. Econ Geol 104(7):905-944. https://doi. org/10.2113/econgeo.104.7.905

Bernstein LR (1985) Germanium geochemistry and mineralogy. Geochim Cosmochim Acta 49(11):2409-2422. https://doi.org/10. 1016/0016-7037(85)90241-8

Bernstein LR (1986) Geology and mineralogy of the APEX germaniumgallium mine, Washington County, Utah. US Geol Surv Bull 1577: $1-9$

Beuchat S, Moritz R, Pettke T (2004) Fluid evolution in the W-Cu-Zn-Pb San Cristobal vein, Peru: fluid inclusion and stable isotope evidence. Chem Geol 210(1-4):201-224. https://doi.org/10.1016/j.chemgeo. 2004.06.008 
Brigo L, Cerrato P (1994) Trace element distribution of Middle-Upper Triassic carbonate-hosted lead-zinc mineralizations: the example of the Raibl deposit (Eastern Alps, Italy), Sediment-hosted Zn-Pb ores, vol. 10 Series Special Publication of the Society for Geology Applied to Mineral Deposits, pp 179-197

Brophy JA (2012) NI 43-101 Technical Report Rio Cristal Resources Corp. Bongará Zinc Project, $104 \mathrm{p}$

Catchpole H, Kouzmanov K, Putlitz B, Seo JH, Fontboté L (2015) Zoned base metal mineralization in a porphyry system: origin and evolution of mineralizing fluids in the Morococha district, Peru. Econ Geol 110(1):39-71. https://doi.org/10.2113/econgeo.110.1.39

Cook NJ, Ciobanu CL, Pring A, Skinner W, Shimizu M, Danyushevsky L, Saini-Eidukat B, Melcher F (2009) Trace and minor elements in sphalerite: a LA-ICPMS study. Geochim Cosmochim Acta 73(16): 4761-4791. https://doi.org/10.1016/j.gca.2009.05.045

Dare S, Barnes SJ, Beaudoin G, Méric J, Boutroy E, Potvin-Doucet C (2014) Trace elements in magnetite as petrogenetic indicators. Mineral Deposita 49(7):785-796. https://doi.org/10.1007/s00126014-0529-0

Dutrizac IE, Jambor JI, Chen TT (1986) Host minerals of the galliumgermanium ores of the Apex Mine. Econ Geol 81:241-281

Fontboté L, Gorzawski H (1990) Genesis of the Mississippi Valley-type $\mathrm{Zn}-\mathrm{Pb}$ deposit of San Vicente, Central Peru: geologic and isotopic (Sr, O, C, S, Pb) evidence. Econ Geol 85(7):1402-1437. https://doi. org/10.2113/gsecongeo.85.7.1402

Frenzel M, Hirsch T, Gutzmer J (2016) Gallium, germanium, indium and other trace and minor elements in sphalerite as a function of deposit type - a meta-analysis. Ore Geol Rev 76:52-78. https://doi.org/10. 1016/j.oregeorev.2015.12.017

Gorzawski H, Fontboté L, Field CW, Tejada R (1990) Sulfur isotope studies in the zinc-lead mine San Vicente, central Peru. SGA Spec Publ 8:305-312

Gregory-Wodzicki KM (2000) Uplift history of the Central Northern Andes: a review. Geol Soc Am Bull 112:1092-1105

Hitzman MW, Reynolds NA, Sangster DF, Allen CR, Carman CE (2003) Classification, genesis, and exploration guides for nonsulfide zinc deposits. Econ Geol 98(4):685-714. https://doi.org/10.2113/ gsecongeo.98.4.685

Höll R, Kling M, Schroll E (2007) Metallogenesis of germanium-a review. Ore Geol Rev 30(3-4):145-180. https://doi.org/10.1016/j. oregeorev.2005.07.034

Jordan TE, Reynolds JH, Erikson JP (1997) Variability in age of initial shortening and uplift in the Central Andes, $16^{\circ}-33^{\circ} 30^{\prime} \mathrm{S}$. In: Ruddiman WF (ed) Tectonic uplift and climate change. Plenum Press, New York, pp 41-61. https://doi.org/10.1007/978-1-4615-5935-1_3

Klein GD, Zúñiga y Rivero FG, Hay-Roe H, Alvarez-Calderon E (2011) A reappraisal of the Mesozoic/Cenozoic tectonics and sedimentary basins of Peru. Search and Discover Article 10332

Kurtz AC, Derry LA, Chadwick OA (2002) Germanium-silicon fractionation in the weathering environment. Geochim Cosmochim Acta 66(9):1525-1537. https://doi.org/10.1016/S0016-7037(01)00869-9

Large D (2001) The geology of nonsulphide zinc deposits - an overview. Erzmetall 54:264-276

Leach DL, Sangster DF, Kelley KD, Large RR, Garven G, Allen CR, Gutzmer J, Walters S (2005) Sediment-hosted lead-zinc deposits: a global perspective. In: Hedenquist JW et al (eds) Economic Geology $100^{\text {th }}$ Anniversary Volume. Society of Economic Geologists, Inc., Littleton, pp 561-607

Longerich HP, Jackson SE, Günther D (1996) Laser ablation inductively coupled plasma mass spectrometric transient signal data acquisition and analyte concentration calculation. J Anal At Spectrom 11(9): 899-904. https://doi.org/10.1039/JA9961100899

Lugolobi F, Kurtz AC, Derry LA (2010) Germanium-silicon fractionation in a tropical, granitic weathering environment. Geochim Cosmochim Acta 74(4):1294-1308. https://doi.org/10.1016/j.gca. 2009.11.027
Mathalone JMP, Montoya RM (1995) Petroleum geology of the subAndean basins of Peru. Am Ass Petrol Geol Mem 62:423-444

Mégard F (1984) The Andean orogenic period and its major structures in central and northern Peru. J Geol Soc Lond 141(5):893-900. https:// doi.org/10.1144/gsigs.141.5.0893

Melcher F (2003) The Otavi Mountain land in Namibia: Tsumeb, germanium and snowball earth. Mitt der Österreichischen Mineral Gesellsch 148:413-435

Melcher F, Buchholz O (2014) Germanium. In: Gunn G (ed) Critical metals handbook. Wiley, Chichester, pp 177-203

Mišković A, Spikings RA, Chew DM, Košler J, Ulianov A, Schaltegger U (2009) Tectonomagmatic evolution of western Amazonia: geochemical characterization and zircon U-Pb geochronologic constraints from the Peruvian Eastern Cordilleran granitoids. Geol Soc Am Bull 121(9-10):1298-1324. https://doi.org/10.1130/B26488.1

Moritz R, Fontboté L, Spangenberg J, Rosas S, Sharp Z, Fontignie D (1996) Sr, C and O isotope systematics in the Pucará basin, Central Peru: comparison between Mississippi Valley-type deposits and barren areas. Mineral Deposita 31(3):147-162. https://doi.org/ 10.1007/BF00204023

Mortlock RA, Froelich PN (1987) Continental weathering of germanium: $\mathrm{Ge} / \mathrm{Si}$ in the global river discharge. Geochim Cosmochim Acta 51(8):2075-2082. https://doi.org/10.1016/0016-7037(87)90257-2

Ostendorf J, Henjes-Kunst F, Schneider J, Melcher F, Gutzmer J (2017) Genesis of the carbonate-hosted Tres Marias $\mathrm{Zn}-\mathrm{Pb}-(\mathrm{Ge})$ deposit, Mexico: constraints from $\mathrm{Rb}-\mathrm{Sr}$ sphalerite geochronology and $\mathrm{Pb}$ isotopes. Econ Geol 112(5):1075-1087. https://doi.org/10.5382/ econgeo.2017.4502

Paradis S (2015) Indium, germanium and gallium in volcanic- and sediment-hosted base-metal sulphide deposits. In: Simandl GJ, Neetz M (eds) Symposium on Strategic and Critical Materials Proceedings, November 13-14, 2015, Victoria, British Columbia. British Columbia Ministry of Energy and Mines, British Columbia Geological Survey Paper 2015-3, pp 23-29

Pfiffner OA, Gonzalez L (2013) Mesozoic-Cenozoic evolution of the western margin of South America: case study of the Peruvian Andes. Geosciences 3(2):262-310. https://doi.org/10.3390/ geosciences 3020262

Pokrovski GS, Schott J (1998a) Thermodynamic properties of aqueous $\mathrm{Ge}(\mathrm{IV})$ hydroxide complexes from 25 to $350^{\circ} \mathrm{C}$ : implications for behavior of germanium and the $\mathrm{Ge} / \mathrm{Si}$ ratio in hydrothermal fluids. Geochim Cosmochim Acta 62(9):1631-1642. https://doi.org/10. 1016/S0016-7037(98)00081-7

Pokrovski GS, Schott J (1998b) Experimental study of the complexation of silicon and germanium with aqueous organic species: implications for germanium and silicon transport and the Ge/Si ratios in natural waters. Geochim Cosmochim Acta 62(21-22):3413-3428. https://doi.org/10.1016/S0016-7037(98)00249-X

Pokrovsky OS, Pokrovski GS, Schott J, Galy A (2006) Experimental study of germanium adsorption on goethite and germanium coprecipitation with iron hydroxide: X-ray absorption fine structure and macroscopic characterization. Geochim Cosmochim Acta 70(13):3325-3341. https://doi.org/10.1016/j.gca.2006.04.012

Reid CJ (2001) Stratigraphy and mineralization of the Bongara MVT zinc-lead district, northern Peru. Unpublished M.Sc. thesis, University of Toronto, Toronto, $179 \mathrm{p}$

Retallack GJ (2010) Laterization and bauxitization events. Econ Geol 105(3):655-667. https://doi.org/10.2113/gsecongeo.105.3.655

Rosas S, Fontboté L, Tankard A (2007) Tectonic evolution and paleogeography of the Mesozoic Pucará basin, central Peru. J S Am Earth Sci 24(1):1-24. https://doi.org/10.1016/j.jsames.2007.03.002

Rottier B, Kouzmanov K, Wälle M, Bendezú R, Fontboté L (2016) Sulfide replacement processes revealed by textural and LA-ICPMS trace element analyses: example from the early mineralization stages at Cerro de Pasco, Peru. Econ Geol 111(6):1347-1367. https://doi.org/10.2113/econgeo.111.6.1347 
Saini-Eidukat B, Melcher F, Lodziak J (2009) Zinc-germanium ores of the Tres Marias Mine, Chihuahua, Mexico. Mineral Deposita 44(3): 363-370. https://doi.org/10.1007/s00126-008-0222-2

Saini-Eidukat B, Melcher F, Göttlicher J, Steininger R (2016) Chemical environment of unusually $\mathrm{Ge}$ - and $\mathrm{Pb}$-rich willemite, Tres Marias Mine, Mexico. Fortschr Mineral 6:1-20

Schneider J, Melcher F, Brauns M (2007) Concordant ages for the giant Kipushi base metal deposit from direct $\mathrm{Rb}-\mathrm{Sr}$ and $\mathrm{Re}-\mathrm{Os}$ dating of sulfides. Mineral Deposita 42(7):791-797. https://doi.org/10.1007/ s00126-007-0158-y

Schroll E (1953) Über Minerale und Spurenelemente, Vererzung und Entstehung der Blei-Zink-Lagerstätte Bleiberg-Kreuth, Kärnten in Österreich. Mitt Österreichischen Mineral Gesellsch, Sonderheft 2:1-60

Scribner AM, Kurtz AC, Chadwick OA (2006) Germanium sequestration by soil: targeting the roles of secondary clays and Feoxyhydroxides. Earth Planet Sci Lett 243(3-4):760-770. https:// doi.org/10.1016/j.epsl.2006.01.051

Sempere T, Hérail G, Oller J, Bonhomme MG (1990) Late OligoceneEarly Miocene major tectonic crisis and related basins in Bolivia. Geology 18(10):946-949. https://doi.org/10.1130/0091-7613(1990) 018<0946:LOEMMT>2.3.CO;2

Silver PG, Russo RM, Lithgow-Bertelloni C (1998) Coupling of South American and African plate motion and plate deformation. Science 297:60-63

Song X (1984) Minor elements and ore genesis of the Fankou lead-zinc deposit, China. Mineral Deposita 19:95-104

Song X, Tan H (1996) Geochemical characteristics of the Fankou Pb-Zn deposits, northern Guangdong, South-China. In: Sangster DF (ed) Carbonate-hosted lead-zinc deposits. SEG Spec Publ 4:350-355

Spangenberg JE, Fontboté L, Sharp ZD, Hunziker J (1996) Carbon and oxygen isotope study of hydrothermal carbonates in the zinc-lead deposits in the San Vicente district, central Peru: a quantitative modeling on mixing processes and $\mathrm{CO}_{2}$ degassing. Chem Geol 133(1-4): 289-315. https://doi.org/10.1016/S0009-2541(96)00106-4

Spangenberg JE, Fontboté L, Macko SA (1999) An evaluation of the inorganic and organic geochemistry of the San Vicente Mississippi Valley type zinc-lead district, central Peru: implications for ore fluid composition, mixing processes, and sulfate reduction. Econ Geol 94(7):1067-1092. https://doi.org/10.2113/gsecongeo.94.7.1067

Spikings R, Reitsma MJ, Boekhout F, Mišković A, Ulianov A, Chiaradia M, Gerdes A, Schaltegger U (2016) Characterisation of Triassic rifting in Peru and implications for the early disassembly of western Pangaea. Gondwana Res 35:124-143. https://doi.org/10.1016/j.gr. 2016.02.008

Takahashi T (1960) Supergene alteration of zinc and lead deposits in limestone. Econ Geol 55(6):1083-1115. https://doi.org/10.2113/ gsecongeo.55.6.1083

White AF, Blum AE (1995) Effects of climate on chemical weathering in watersheds. Geochim Cosmochim Acta 59(9):1729-1747. https:// doi.org/10.1016/0016-7037(95)00078-E

Wood SA, Samson IM (2006) The aqueous geochemistry of gallium, germanium, indium and scandium. Ore Geol Rev 28(1):57-102. https://doi.org/10.1016/j.oregeorev.2003.06.002

Workman A, Breede K (2016) NI 43-101 Technical report on the Bongará zinc project in the Yambrasbamba area, northern Peru, $139 \mathrm{p}$

Wright C (2010) NI 43-101 Technical report on the Rio Cristal Resources Corp. Bongará Zinc Project (Peru), $102 \mathrm{p}$

Zachariáš J, Wilkinson J (2007) ExLAM 2000: excel VBA application for processing of transient signals from laser ablation (LA-ICPMS) of fluid inclusions and solid phases. ECROFI-XIX Biennial Conference on European Current Research on Fluid Inclusions, Bern, Switzerland 